\title{
Anamorfik illüzyonun Mekan Algısına Etkilerinin Farklı Sanatçı Yaklaşımlarına Göre İrdelenmesi
}

\author{
Yrd. Doç. Dr. Yasemin Erkan Yazıcı
}

\section{Öz}

Mekân sadece bir hacim değil, aynı zamanda tüm duyu organları ile birlikte algılanan, sınırları kullanıcı tarafından oluşturulabilen bir boşluktur. Bazen tasarımcılar üç boyutlu elemanlarla mekânda istedikleri etkileri yaratamamaktadırlar. Bu gibi durumlarda anamorfik illüzyon olarak adlandırılan, iç ya da dış mekanlarda uygulanabilen yöntemden yararlanılabilir. Bu yöntem derinlik, süreklilik, yönlendirme, odaklanma ve merak gibi mekânda istenilen algıyı yaratmak için kullanılabilir. Bu makalede anamorfik çalışmalar yapan sanatçıların yaptıkları çalışmalar incelenmiş ve bu çalışmaların mekânda oluşturduğu algı değişiklikleri olumlu ve olumsuz yanları ile birlikte değerlendirilmiştir.

Anahtar Kelimeler: Algı, Görsel Algı, Mekan Algısı, Anamorfik IIllüzyon

\section{INVESTIGATION OF THE EFFECTS OF ANAMORPHIC ILLUSION ON SPATIAL PERCEPTION ACCORDING TO THE APPROACHES USED BY VARIOUS ARTISTS}

\begin{abstract}
Space is not only a volume, but at the same time it is a space perceived with all sensory receptors and its boundaries can be created by the user. At times, designers are unable to provide the intended effects in space with three dimensional elements. In these cases, it is possible to make use of a method called "anamorphic illusion", which can be used in both interior and exterior spaces. This method can used to create a desired perception of depth, continuity, directivity, focus and curiosity in space. This presents investigates the works of artists who make use of anamorphic illusion and evaluates the positive and negative effects of this technique on the perception of space.
\end{abstract}

Keywords: Perception, Visual Perception, Spatial Perception, Anamorphic Illusion 


\section{Giriş}

Algı, genellikle psikolojinin konusudur ancak fizik, biyoloji, fizyoloji, felsefe, sanat felsefesi ve estetiğin de konusu olmuştur. Algı, çevredeki nesneleri, olayları, ilişkileri duyu organları yoluyla anlama ve anlamlandırma sürecidir. Algı sürecinde, biçimleri tanıma, birbirinden ayırma, bir araya getirerek anlam çıkarma gibi karmaşık işlevler yerine gelmektedir ${ }^{1}$.

Bireyler, çevrelerindeki olaylara ve kavramlara ilişkin bilgileri, algılama yoluyla edinmektedirler. Algı, bireylerin çevresinden edindikleri duyusal bilgilerin farkına varıp anlamlandırdıkları bir süreçtir. Bireyler bu süreç sonunda uyaranları kendileri için anlamlı hale getirmektedirler (Siegel, 2006; Smith, 2002; Demirel, 1993).

Algılama sürecindeki en önemli kriter bireydir. Bireyler, algılanan aynı kavramla ilgili farklı algısal özellikler ortaya koyabilirler. Bunun nedenleri, algı sürecindeki seçici dikkat, seçici algısal değişkenler ve seçici algısal kalıcilıktır (Kotler, 2001).

Algı, duyu izlenimlerinin yorumlanması, görsel algı ise bireyin gördüğünü kavrama yeteneğidir. Bireyin neyi göreceği, nasıl algılayacağı, hangi görüntüleri algılayıp hangilerini algılayamayacağı, algıladığı görüntülere ne tür anlamlar yükleyeceği, onun bilgi birikimi ve geçmiş deneyimiyle ilgilidir. Görsel algılamanın gerçekleşebilmesi için bireyin psikolojik olarak bakma ve görme eylemine hazır olması gerekir. Burada bireyin, etrafını saran görüntü karmaşası içinden neyi görmek istediği, görsel algılamanın gerçekleşmesi sürecinde önem taşımaktadır (İnceoğlu, 2004:83,84).

Görsel algı süreci duyusal ve zihinsel süreçlerden gelen görsel bilgilerin algılanması ve işlenmesi süreci olarak tanımlanabilir (Gal ve Linchevski, 2010). Görsel algılama sürecinde algıyı oluşturması amaçlanan içeriğin özelliği ve etkin bir mesaj içermesi görsel tasarımın niteliğini artırmaktadır. Tasarım sürecinde algıyı oluşturacak kavram, nesne ya da etkinliklerin öne çıkan özelliklerinin kullanılması algılamada etkinlik açısından önemlidir (Smeulders vd., 2000). Görsel algılama sürecinde, görsellere ilişkin algıyı, bir takım tasarım öğeleri ve ilkeleri oluşturmaktadır (Smeulders vd., 2000)².

Görsel algılama sürecinde bireyler algılanan kavramla ilgili olarak ilk önce yüzeysel bir edinim süreci yaşarlar. Bu iki boyutlu bir süreçtir. Bu aşamada bireyler görselleri sadece ebatlarıla algılarlar. Bu süreç sonrasında birey, görsele ilişkin daha derinlemesine bir örüntü oluşturmaya başlar. Böylece derinlik algısı ile birlikte üçüncü boyut devreye girer. Son aşamada kültürel

I http://gsf.baskent.edu.tr

2 http://www.georgesrousse.com 
alt yapısı ile kavramı anlamlandırır ve kavrama bir kimlik kazandırır (Booth, 2003; Findlay ve Gilchrist, 2003).

M. Frostig, Lefever ve Whittlesey görsel algı ölçümünde el-göz koordinasyonu, şekil-zemin, şekil değişmezliği, mekânda konum ve uzamsal ilişkiler olmak üzere beş farklı ölçütten bahsetmiştir (Hammill, Pearson ve Voress, 1993:7).

Hammil vd. (1993) ise sekiz alt test; el-göz koordinasyonu, mekânda konum, kopyalama, şekil-zemin, uzamsal ilişkiler, görsel tamamlama, görsel-motor hız ve şekil değişmezliği ve bu alt testlerden oluşturulan üç boyut; genel görsel algı, motor-bağımsız görsel algı, görsel-motor algı ile görsel algıyı değerlendirmiştir.

\section{Mekân Algısı: Anamorfik illüzyon}

Mekânı, çevresinden farklılaşan alan olarak tanımlayan Eyüce (2005), mekan sınırlarının kullanıc tarafından tanımlanabileceğini vurgulamışır. Sadece bir alan ya da hacim olarak ele alınmaması gereken mekân kavramı farklı kullanımlara göre çeşitlilik gösterebilir. Bir mahalle esnafının dükkânının önünde suladığı alan, bir çocuğun oyuncaklarıyla oluşturduğu sınır, havada dolaşan parfüm kokusu, müzik sesini içine alan hacim...

Mekan tanımına algıyı da dâhil eden Norberg-Schulz (1968), mekanın onu oluşturan öğelerle birlikte ele alınması gerektiğini savunmaktadır. Mekân algısında sınırlayıcı öğeler büyük rol üstlenmektedir. Bu öğeler, yatay düşey ve diğer yüzeyler olabileceği gibi, yüzey niteliklerinin başkalaştığı doku ve renk değişimleri de olabilir. Bu sınırlayıcıları, hacimsel (duvar, çit, peyzaj öğeleri vs.) ve çizgisel (doku ve renk farklılıkları) olarak ayırmak mümkün olabilmektedir.

Tasarımcl; yönlendirme, hareketlilik, bir yere odaklama gibi mekânda farklı algılara neden olabilecek eylemleri, mimari öğelerle tam olarak sağlayamayabilir ya da çeşitli nedenlerden dolayı tercih etmeyebilir. Bu durumda anamorfik illüzyon olarak adlandırılan tasarımlar devreye girebilir. Genellikle geometrik desenlerden oluşan bu tasarımlar iç ya da dış mekânlarda uygulanabilir.

Bazı anamorfik tasarımların uygulama sürecinde sanatçı, projeksiyon cihazını kullanarak belirlediği şekli istediği yüzeye yansıtmakta, daha sonra belirlenen noktadan bakılınca algılanacak şekilde yüzeye uygulamaktadır. Fotoğraf 1'de anamorfik illüzyon uygulanmış mekanlar yer almaktadır. Farklı yüzeylere yapılan bu uygulamalar belirli noktadan bakılınca aynı yüzeydeymiş gibi algılanmakta, belirlenen nokta dışında bakılınca ise 
anlamsız şekiller gözükmektedir. Uygulandığı mekânlarda oldukça çarpıcı ve şaşırtıcı sonuçlar oluşturan bu çalışmaları yapan anamorfik grafiti sanatçıları arasında Felice Varini, Nils Nova, Georges Rousse ve Erik Johansson sayılabilir.

Bu çalışmalarda üç farklı mekân söz konusu olmaktadır. Birincisi çalışmanın yapılmadığı gerçek mekân, ikincisi sanatçının icat ettiği ve seçtiği alana dikkatlice inşa ettiği hayali mekân, üçüncüsü ise tek bir noktadan görülebilen, sadece çekilen fotoğrafta var olan yeni bir mekândır³.
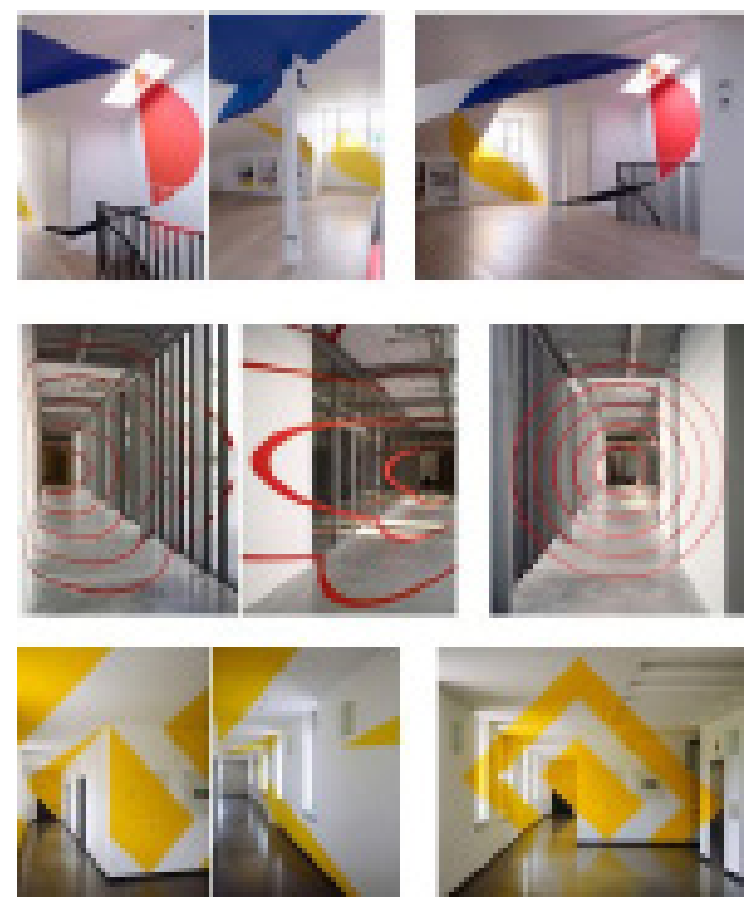

Fotoğraf 1: Fellice Varini, Anamorfik illüzyon uygulanmış mekanlar, sıra ile 2011-2007-1997, duvara boya.

Anamorfikillüzyon alanında öncülerden biri olan Felice Varini çalışmalarında genellikle daire, kare, üçgen gibi asal geometrik şekiller kullanmaktadır. Oluşturduğu geometrik desenleri dar koridorlara, boşluklara, merdivenlere yerleştirerek belirli bir doğrultuda yönlendirme sağlamaktadır ${ }^{4}$ (Fotoğraf 2).

3 http://www.sanatblog.com

$4 \mathrm{http} / / / w w w . g o r s e l s a n a t l a r . o r g$ 

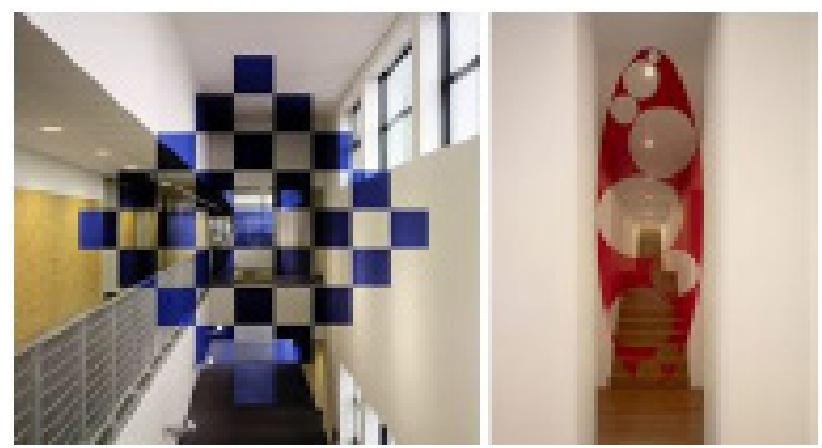

Fotoğraf 2: Felice Varini, Yönlendirme çalışmaları, 2010, boya.

Felice Varini tuval olarak kullandığı mimari mekânları son zamanlardaki çalışmalarında abartarak yapılara, caddelere ve meydanlara taşımışıı. Farklı açılarda yerleşmiş birkaç bina yüzeyini ya da tek bir yapının farklı yüzeylerini kullandığı çalışmalarda belirli bir noktaya dikkat çekme ya da odaklama gibi etkiler yaratmaktadır (Fotoğraf 3).

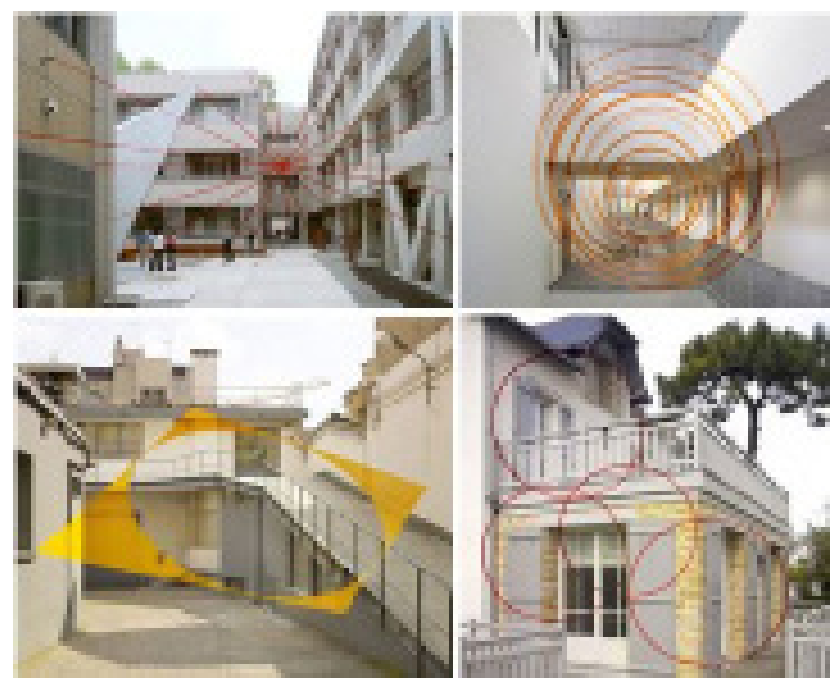

Fotoğraf 3: Fellice Varini, Odaklanma / Dikkat çekme çalışmaları, sol üst 2008-diğerleri 2010, boya.

Fotoğraf ve çoklu ortam (multimedia) sanatçıSı Georges Rousse ISSIZ binalarda, renkli ve geometrik desenli anamorfik illüzyonlar yaratmaktadır (Fotoğraf 4). Georges yaptığı çalışmalarda mekâna hareket ve canlılık katmaktadır. 

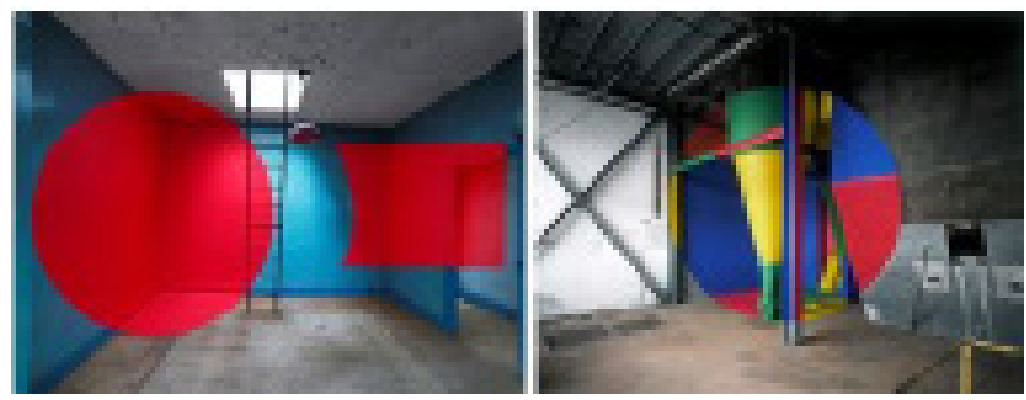

Fotoğraf 4: Georges Rousse, Hareketlilik çalışmaları, soldaki 2012-sağdaki 2003, boya.

Anamorfik grafiti sanatçılarından Nils Nova çalışmalarında, Felice Varini ve Georges Rousse'dan farklı bir yöntem uygulamıştır. Onun çalışmalarında belirli bir noktadan bakılma zorunluluğu yoktur. Genellikle çalışmalarını iç mekânda gerçekleştirmektedir. İç mekân sergi alanlarında yaptığı çalışmalarda, duvar yüzeyleri mekânın devamı gibi görünmektedir (Fotoğraf 5). Böylece mekânın boyutları olduğundan daha geniş ya da daha derin algılanmaktadır ${ }^{5}$.

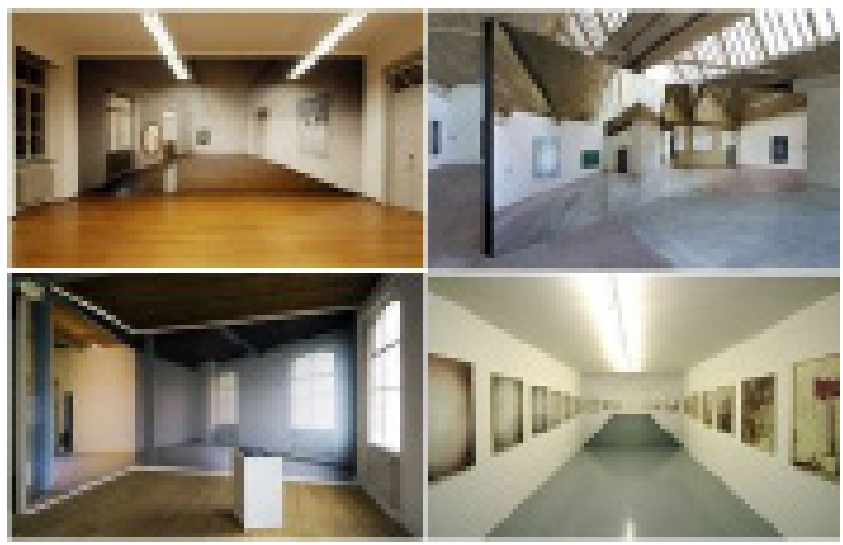

Fotoğraf 5: Nils Nova, Süreklilik / derinlik çalışmaları, 2011, boya.

İsveçli rötuş sanatçısı Erik Johansson'ın çalışmalarında da Nils Nova'nın çalışmaları gibi belirli bir noktadan bakma zorunluluğu yoktur. Nils Nova anamorfik çalışmalarını genellikle duvaryüzeyine, Erik Johansson ise zemine uygulamaktadır. Erik Johansson'un bu alanda yaptığı çalışmalara 7-12 June 2011 tarihleri arasında Stockholm'de bir meydanda yaptığı çalışma örnek gösterilebilir (Fotoğraf 6). 32×18 m ebadında dev bir çukuru anımsatan ve

5 http://www.nilsnova.tv 
"Mind your step" olarak adlandırılan çalışma meydana gelenlerin bir anlık duraksamasına ve şaşırmasına neden olmaktadır ${ }^{6}$.

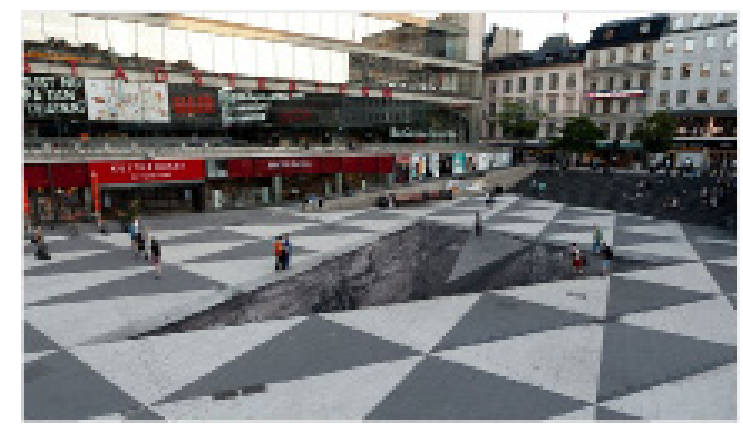

Fotoğraf 6: Erik Johansson, Şaşırtma çalışmaları, 2011, zemin çalışması.

\section{Sonuç}

Mekanı sadece bir hacim olarak düşünmeyip, aynı zamanda tüm duyu organlarıilebirliktealgılanan, sınırlarınınkullanıcıtarafındanoluşturulabildiği bir boşluk olarak ele almak gerekir. Bu boşlukta tasarımcıların mekânda istedikleri, derinlik, süreklilik, yönlendirme, odaklanma, hareket ve merak gibi etkileri yaratamadıkları ya da çeşitli sebeplerle yaratmak istemedikleri durumlar söz konusu olabilir. Bu gibi durumlarda makalede sözü edilen anamorfikillüzyon olarakadlandırılan, içya da dışmekanlarda uygulanabilen yöntemden yararlanılabilir.

Felice Varini ve Georges Rousse'nun çalışmaları incelendiğinde, bir noktaya dikkat çekme, belirli bir doğrultuya yönlendirme, çok durağan bir mekâna hareket katma, girişlerin vurgulanması, açık alanlarda meydanın tanımlanması, ilişkili olan yapıların belirlenmesi gibi birçok eylem için uygulandığı görülmektedir. Nils Nova'nın çalışmalarında ise mekanı olduğundan büyük gösterme, geniş ve derin mekanlar yaratma, yönlendirme gibi etkiler göze çarpmaktadır. Erik Johansson yaptığı çalışmalarda teknolojiyi kullanarak çektiği fotoğrafları fantastik görüntülere dönüştürmektedir.

Bu çalışmalarının yanısıra birkaç anamorfik illüzyon çalışması da vardır. İç ve dış mekanlarda uyguladığı bu çalışmalar incelendiğinde, mekana düşey olarak derinlik katma, zemin altını yansıtma gibi detayların belirgin olduğu görülmektedir.

Felice Varini ve Georges Rousse'nun çalışmalarının dezavantajı sadece

6 http://erikjohanssonphoto.com 
belirlenen noktadan durup bakıldığında ana şeklin algılanması, açı değiştirildiğinde ise bir yığın anlamsız şeklin gözükmesidir. Bu durum dezavantaj olarak görülmeyip, bu anlamsız şekillerin kişide uyandırdığı merak etkisiyle sanki yapboz parçalarını birleştirircesine doğru bakış noktası bulunmaya çalışılması, mekânda yaratılan dinamik etki olarak düşünülebilir. Nils Nova ve Erik Johansson'un çalışmalarının dezavantajı ise mekânın yatayda ya da düşeyde devam ettiğini düşünen kişilerin, devam etmediğini fark ettiğinde hissedebileceği rahatsızlıktır. 


\section{Kaynakça}

Booth, R.G. (2003). Perception of the Visual Environment, New York: Springer.

Demirel, Ö. (1993). Eğitim Terimleri Sözlüğü, Ankara: Usem Yayınları.

Eyüce, A. (2005). Geleneksel Yapılar ve Mekânlar, İstanbul: Birsen Yayınları.

Findlay, J.M., Gilchrist, I.D. (2003). Active Vision: The Psychology of Looking and Seeing, England, Oxford: Oxford University Press.

Gal, H., Linchevski, L. (2010). To See or not to See: Analyzing Difficulties in Geometry from the Perspective of Visual Perception. Educational Studies in Mathematics. 74, 163-183.

Hammill, D.D., Pearson, N.A., Voress, J.K. (1993). Developmental Test of Visual Perception-2nd Ed., Examiner's Manual. Texas: Pro-Ed. Pub.

İnceoğlu, M. (2004). Tutum-Algı İletişim, Ankara: Elips Kitap.

Kotler, P. (2001). A Framework for Marketing Management. Upper Saddle River. Prentice Hall, NJ.

Norberg-Schulz, C. (1968). Intentions in Architecture, USA: MIT Press.

Siegel, S. (2006). "Which Properties are Represented in Perception?". Perceptual Experience, der. T. Gendler \& J. Hawthorne, Oxford: Oxford University Press.

Smeulders, A.W.M., Worring, M., Santini, S., Gupta, A., Jain, R. (2000). "Content-Based İmage Retrieval at the end of the Early Years". IEEE Transactions on Pattern Analysis and Machine Intelligence. 22 (12), 1349-1380.

Smith, A.D. (2002). The Problem of Perception, Cambridge, MA: Harvard University Press.

\section{İnternet Kaynakları}

1 İnternet: Erder, F. (2014). Algı, Web: http://gsf.baskent.edu.tr/duyuru/1ALGI.doc adresinden 18 Temmuz 2014'de alınmıştır.

2 Internet: Eidenberger, H. (2004). A new perspective on visual information retrieval. SPIE Electronic Imaging Symposium, San Jose, Web: http://www.georgesrousse.com adresinden 10 Temmuz 2014'de alınmıştır.

3 Internet: Sanat Blog. (2014). Web: http://www.sanatblog.com/etiket/anamorfik 22 Temmuz 2014'de alınmıştır. 
4 İnternet: Görsel Sanatlar Platformu. (2014). Web: http://www.gorselsanatlar.org/icmimarlik-ve-cevre-tasarimi/felice-varini-(-anamorfik-sanati-) 23 Temmuz 2014'de alınmıştır.

5 İnternet: Nils Nova. (2014). Web: http://www.nilsnova.tv 23 Temmuz 2014'de alınmıştır.

6 İnternet: Erik Johansson. (2014). Web: http://erikjohanssonphoto.com/work/mindyour-step 19 Ocak 2015'de alınmıştır.

\section{Görsel Kaynakları}

Fotoğraf 1: Web: http://www.themost10.com/impressive-anamorphic-illusions-byfelice-varini adresinden 6 Haziran 2014'de alınmıştır.

Fotoğraf 2: Web: http://www.varini.org adresinden 6 Haziran 2014'de alınmıştır.

Fotoğraf 3: Web: http://inspir3d.net/2012/03/03/fantastic-anamorphic-illusions-byfelice-varini adresinden 6 Haziran 2014'de alınmıştır.

Fotoğraf 4: Web: http://www.claire-gastaud.com/artist/Georges-ROUSSE adresinden 17 Temmuz 2014'de alınmıştır.

Fotoğraf 5: Web: http://wheresnick.wordpress.com/2011/04/23/impossible-spacesoptical-illusions adresinden 6 Haziran 2014'de alınmıştır.

Fotoğraf 6: Web: http://erikjohanssonphoto.com/work/mind-your-step adresinden 19 Ocak 2015'de alınmıştır. 